\title{
Konsentrasi Protein dan Asam Amino pada Ikan Gabus (Channa striata) yang Diberi Daging Keong Mas (Pomacea sp) Segar atau Kering
}

\section{Protein and Amino Acid Concentrations in Snakehead (Channa striata) Given Meat Apple Snail (Pomacea sp) Fresh}

\author{
Jumriati $^{\left.12)^{*}\right)}$, Muhammad Idris ${ }^{3)}$, Yusnaini ${ }^{3)}$ \\ 1) Program Studi Ilmu Perikanan Program Pascasarjana Univ. Halu Oleo, Kendari, Indonesia \\ ${ }^{2)}$ Dinas Ketahanan Pangan Kabupaten Konawe, Konawe, Indonesia \\ ${ }^{3)}$ Fak. Perikanan dan Ilmu Kelautan Universitas Halu Oleo, Kendari, Indonesia \\ Corresponding autors $^{*}$ : jumriatijum08@gmail.com
}

\begin{abstract}
ABSTRACK
This study aims to determine the concentration of protein and amino acids in Snakehead that are given apple snail fresh or dried. Used Snakehead with a total length of 7-10 cm and average initial weight of $5 \mathrm{~g}$ of 60 heads. Fish kept in a circular concrete tub with a diameter of $80 \mathrm{~cm}$ and height $50 \mathrm{~cm}$, filled with water as much as 100 liters, then fish stocked density 10 tail/unit. Fish feeding test is done 2 times a day at 06.00-07.00, and 17.0018.00. Apple snail are given $15 \%$ of the fish body weight of Snakehead. Variables of this study, absolute growth, protein retention, changes in amino acid composition of Snakehead. The results showed that after maintenance of 60 days of absolute growth of Snakehead by giving fresh apple snail $(2.79 \pm 1.21 \mathrm{~g})$ and was given dried apple snail $(1.87 \pm 0.92 \mathrm{~g})$. Protein retention in snakehead with fresh apple snail $(1.31 \pm 1.42 \%)$, and with dried mask $(0.37 \pm 0.82 \%)$. A total of 15 amino acids obtained in Snakehead are divided into 8 essential amino acids namely, lysine, leucine, arginine, threonin, phenylalanine, isoleucine, valine and histidine, and 7 non essential acids ie glutamic acid, aspartic acid, alanine, glycine, tyrosine, serine, and proline. Research can be concluded that giving fresh apple snail meat effect on growth and high protein retention in snakehead.
\end{abstract}

Keywords : Amino acids, snakehead, apple snail.

\begin{abstract}
ABSTRAK
Penelitian ini bertujuan mengetahui konsentrasi protein dan asam amino pada ikan gabus yang diberi pakan berupa daging keong mas segar atau kering. Ikan gabus berukuran panjang total 7-10 $\mathrm{cm}$ dan berat awal rata-rata $5 \mathrm{~g}$ sebanyak 60 ekor. Ikan dipelihara dalam bak beton berbentuk bundar, diameter $80 \mathrm{~cm}$ dan tinggi $50 \mathrm{~cm}$, diisi air 100 l. Ikan ditebar kepadatan 10 ekor/bak, pakan ikan uji diberikan 2 kali sehari pukul 06.00-07.00 dan 17.00-18.00. Daging uji, daging keong mas diberikan 15\% dari bobot tubuh ikan. Variabel yang diamati yaitu pertumbuhan mutlak, retensi protein, komposisi asam amino ikan gabus. Hasil penelitian menunjukan bahwa setelah pemeliharaan 60 hari, pertumbuhan mutlak pada pemberian daging keong mas segar $(2,79 \pm 1,21 \mathrm{~g})$ dan daging keong mas kering $(1,87 \pm 0,92 \mathrm{~g})$. Retensi protein ikan yang diberi daging keong mas segar $(1,31 \pm 1,42 \%)$, dan diberi daging keong mas kering $(0,37 \pm 0,82 \%)$. Sebanyak 15 asam amino yang didapatkan pada ikan gabus, 8 asam amino esensial yaitu lisin, leusin, arginin, threonin, fenilalanin, isoleusin, valin dan histidin, serta 7 asam amino non esensial yaitu asam glutamat, asam asparat, alanin, glisin, tirosin, serin, dan prolin. Lisin merupakan asam amino tertinggi. Disimpulkan bahwa pemberian daging keong mas segar cenderung lebih tinggi pada pertumbuhan dan retensi protein yang tinggi pada ikan gabus dari pada keong dalam bentuk kering.
\end{abstract}

Kata Kunci : Asam amino, pakan, ikan gabus, keong mas.

DOI: http://dx.doi.org/10.33772/jspi.v2n1. 


\section{PENDAHULUAN}

Ikan gabus (Channa striata) merupakan salah satu jenis ikan air tawar yang memiliki nilai ekonomis yang cukup tinggi. Produksi ikan gabus masih mengandalkan tangkapan dari alam, dengan semakin intensifnya penangkapan ikan gabus memberikan dampak terhadap menurunnya populasi ikan gabus di alam. Berdasarkan data statistik tahun 2008 ikan gabus yang tertangkap di perairan umum sebesar 25.842 ton atau turun sekitar $15 \%$ dibanding tahun 2007 yaitu sebesar 28.042 ton 9 (Anonimous, 2010). Maka dikuatirkan ketersediaan ikan gabus di alam akan semakin berkurang, untuk mengatasi hal tersebut maka perlu dilakukan usaha budidaya.

Dalam usaha budidaya, pakan sangat berpengaruh terhadap pertumbuhan ikan. Protein merupakan nutrien yang sangat dibutuhkan dalam pertumbuhan ikan, karena protein sebagai komponen terbesar dari daging dan berfungsi sebagai bahan pembentuk jaringan tubuh (Harver, 1988). Protein dengan kualitas dan jumlah tertentu mempengaruhi pertumbuhan sehingga pemberian protein yang cukup dalam pakan secara kontinu sangat dibutuhkan agar dapat diubah menjadi protein tubuh secara efisien (NRC, 1983).

Sumber potein pakan ikan salah satunya bersumber dari keong mas (Pomacea $s p$ ). Dari hasil uji proksimat diketahui keong mas mengandung protein yang relatif tinggi yaitu16-50\%. Penggunaan keong mas untuk pakan crustacea khususnya pada udang dan kepiting, telah dilakukan dipantai Mayangan (Subang) tahun 1995, hasil uji coba menunjukkan bahwa pemberian pakan berupa keong mas dapat mempersingkat sampai $1 / 3$ kali masa pemeliharaan dibanding dengan pemberian pakan yang berasal dari ikan (DKP. Subang, 1995).

Penggunaan daging keong mas sebagai pakan pada ikan gabus, potensial diterapkan karena ikan gabus sebagai ikan karnivora. Sebagai ikan karnivora kemungkinan lebih menyukai pakan dalam bentuk segar, namun pakan dalam bentuk kering lebih praktis. Daging keong mas akan memberikan pengaruh terhadap retensi protein dan komposisi asam amino. Berdasarkan hal tersebut, maka perlu dilakukan penelitian tentang " Konsentrasi Protein dan Asam Amino pada Ikan Gabus (Channa striata) yang diberi Daging Keong Mas (Pomacea sp) Segar dan Kering". Penelitian ini bertujuan untuk mengetahui perbedaan retensi protein dan komposisi asam amino pada ikan gabus yang diberi pakan keong mas segar dan kering.

\section{METODE PENELITIAN}

Komposisi asam amino dengan hidrolisis asam pada pengujian asam amino menggunakan alat Ultra Performance Liquid Chromatography (UPLC).

Ikan uji adalah ikan gabus yang diperoleh dari Balai Benih Ikan, Kecamatan Ranomeeto, Kab. Konawe Selatan. Panjang total 7-10 cm dan berat awal rata-rata 5 g sebanyak 60 ekor. Pakan uji dibuat dengan bahan dasar keong mas. Daging keong mas yang diberikan pada ikan gabus yakni keong mas segar atau kering. Hasil analisis proksimat pakan keong mas segar dan kering disajikan pada Tabel 1:

Tabel 1. Hasil analisis proksimat pakan keong mas segar dan kering

\begin{tabular}{cccccc}
\hline Pakan & Pomposisi nutrisi (\%) & \\
& Protein & Air & Lemak & $\begin{array}{c}\text { Serat } \\
\text { kasar }\end{array}$ & Abu \\
\hline $\begin{array}{c}\text { Keong } \\
\text { mas segar } \\
\text { Keong } \\
\text { mas } \\
\text { kering }\end{array}$ & 16,26 & 80,58 & 1,67 & 0,32 & 0,76 \\
\hline
\end{tabular}

Wadah yang digunakan dalam penelitian ini adalah bak beton berbentuk lingkaran diameter $80 \mathrm{~cm}$ dan tinggi $50 \mathrm{~cm}$ sebanyak 6 buah. Wadah pemeliharaan diisi dengan air, dengan volume air dalam masing-masing wadah pemeliharaan. Sebagai ilustrasi percobaan di lapangan dapat dilihat pada Gambar 1 berikut ini :

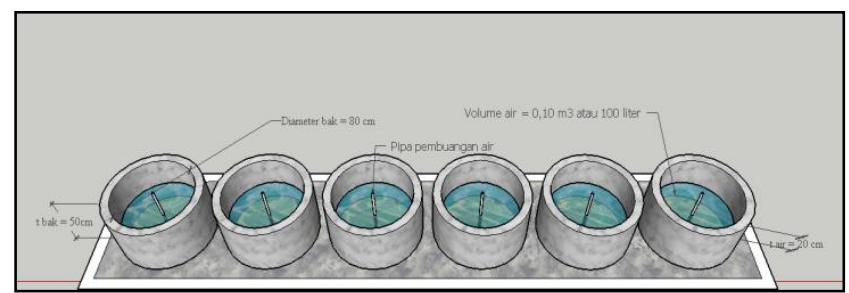

Gambar 1. Desain bak pemeliharaan

Sebanyak 10 ekor ikan gabus ditebar dalam setiap bak pemeliharaan dan dilakukan proses adaptasi terhadap kualitas air yang optimal untuk kehidupan ikan gabus. Selama proses adaptasi, ikan diberi pakan komersil. Ikan gabus ditimbang terlebih dahulu sebelum dilakukan penelitian untuk mengetahui bobot biomassa awal ikan gabus. 
Pemberian pakan ikan uji dilakukan sebanyak 2 kali sehari, pada pukul 06.00-07.00, dan 17.00-18.00. Daging keong mas segar atau kering diberikan $15 \%$ dari bobot tubuh ikan gabus. Penyiponan dilakukan setiap hari agar sisa pakan dapat dikeluarkan. Pengamatan kualiatas air meliputi pengukuran suhu air dengan thermometer, $\mathrm{pH}$ dilakukan pada awal dan akhir penelitian. Pengambilan sampel oksigen terlarut, dan amoniak dilakukan pada akhir penelitian.

\section{Analisis Data}

Analisis data dilakukan secara deskriptif yaitu penggambaran perubahan nilai pertumbuhan mutlak, retensi protein dan asam amino ikan gabus serta nilai parameter kualitas air.

\section{Pertumbuhan Mutlak}

Perhitungan pertumbuhan mutlak berdasarkan bobot tubuh digunakan rumus Soltanzadeh (2015) yaitu :

$\mathrm{Wm}=\mathrm{Wt}-\mathrm{Wo}$

Keterangan :

$\mathrm{Wm}=$ Pertumbuhan mutlak $(\mathrm{g})$

$\mathrm{Wt} \quad=$ Biomassa individu pada waktu $\mathrm{t}(\mathrm{g})$

Wo = Biomassa individu pada awal penelitian $(\mathrm{g})$

\section{Retensi Protein}

Retensi Protein (RP) yang dirumuskan oleh Thung dan Shiau (1991) dalam Agustono, $d k k$ (2012). sebagai berikut :

$\mathrm{RP}=\frac{\mathrm{BPT}-\mathrm{BPO}}{\mathrm{TPK}} \times 100 \%$

Keterangan :

BPT $=$ Nilai Protein tubuh akhir

$\mathrm{BPO}=$ Nilai Protein awal

TPK = Total protein pakan yang diberikan

\section{Asam Amino}

Persentase perubahan asam amino pada ikan gabus dihitung menggunakan rumus :

$\mathrm{PAA}=\frac{\mathrm{AAT}-\mathrm{AA} 0}{\mathrm{AA} 0} \times 100 \%$

Keterangan :

$\mathrm{PAA}=$ Perubahan asam amino

$\mathrm{AAT}=$ Asam amino akhir

AA0 $=$ Asam amino awal

\section{HASIL DAN PEMBAHASAN}

Rata-rata pertumbuhan mutlak setiap perlakuan disajikan pada Gambar 2.

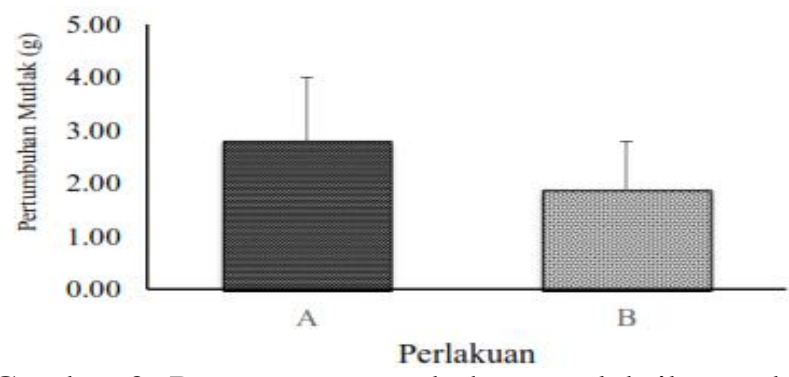

Gambar 3. Rata-rata pertumbuhan mutlak ikan gabus yang dipelihara selama 60 hari. Perlakuan A (pemberian daging keong mas segar); Perlakuan B (pemberian daging keong mas kering)

Berdasarkan hasil penelitian yang dilakukan selama 60 hari, menunjukan rata-rata pertumbuhan mutlak ikan gabus dengan pemberian daging keong mas segar $(2,79 \pm 1,21 \mathrm{~g})$ dan ikan gabus yang diberi daging keong mas kering $(1,87 \pm 0,92 \mathrm{~g})$.

\section{Retensi Protein Ikan Gabus}

Rata-rata retensi protein pada ikan gabus yang diberi daging keong mas segar $(1,31 \pm 1,42 \%)$, dan rata-rata retensi protein ikan gabus yang diberi daging keong mas kering $(0,37 \pm 0,82 \%)$. Retensi protein ikan gabus disajikan pada Gambar 4.

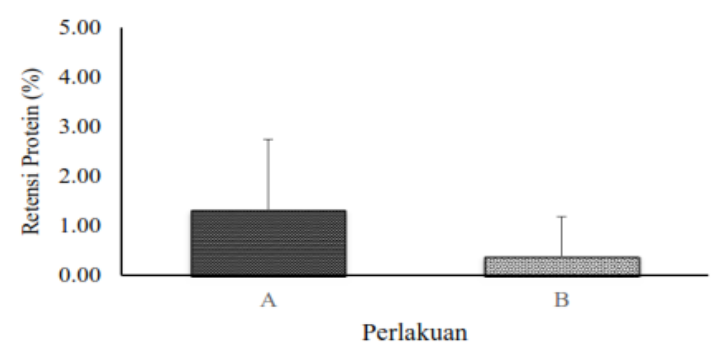

Gambar 4. Rata-rata retensi protein ikan gabus yang dipelihara selama 60 hari. Perlakuan A (daging keong mas segar); Perlakuan B (daging keong mas kering).

\section{Asam Amino}

\section{a. Asam Amino Esensial}

Hasil penelitian menunjukan bahwa rata-rata komposisi lisin pada ikan gabus awal $(1,92 \%)$, setelah pemberian daging keong mas dengan komposisi lisin keong mas segar $(0,90 \%)$ dan keong mas kering $(1,25 \%)$, rata-rata komposisi lisin ikan A $(2,05 \%)$ dan ikan B (1,92\%). Komposisi lisin pada ikan gabus sebelum pemberian daging keong mas dan setelah pemberian daging keong mas serta lisin pada daging keong mas disajikan pada Gambar 5. 


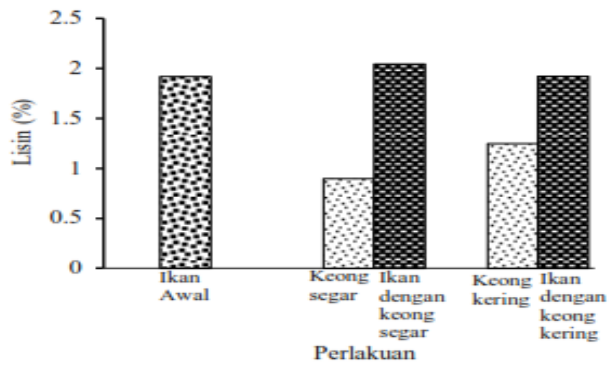

Gambar 5. Komposisi dan persentase perubahan lisin dengan pemberian daging keong mas: Perlakuan A (daging keong mas segar); Perlakuan B (daging keong mas kering).

Pemberian daging keong mas pada ikan gabus memberikan pengaruh peningkatan lisin. Persentase perubahan lisin dengan pemberian daging keong mas segar sebesar $6,60 \%$ sedangkan yang diberi daging keong mas kering sebesar $0,23 \%$.

Komposisi leusin pada ikan gabus awal (1,30\%). Setelah pemberian daging keong mas dengan komposisi leusin keong mas segar $(0,92 \%)$ dan keong mas kering $(1,19 \%)$, rata-rata komposisi leusin ikan A $(1,38 \%)$ dan ikan B $(1,43 \%)$. Pemberian daging keong mas pada ikan gabus memberikan pengaruh perubahan leusin. Persentase perubahan leusin dengan pemberian daging keong mas segar sebesar 6,29\% sedangkan yang diberi daging keong mas kering sebesar $10,27 \%$. Komposisi leusin pada ikan gabus dan daging keong mas disajikan pada Gambar 6.

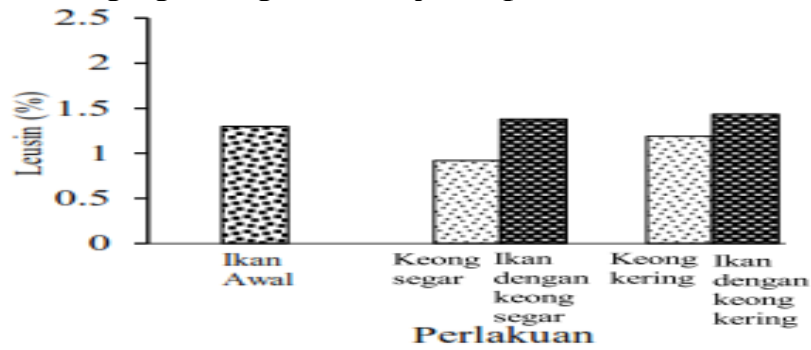

Gambar 6. Komposisi leusin dan persentase perubahan leusin dengan pemberian daging keong mas: Perlakuan A (daging keong mas segar); Perlakuan B (daging keong mas kering).

Komposisi arginin pada ikan gabus awal $(0,87 \%)$. Setelah pemberian daging keong mas dengan komposisi arginin keong mas segar $(1,02 \%)$ dan keong mas kering $(1,16 \%)$, rata-rata komposisi arginin ikan A $(1,01 \%)$ dan ikan B $(1,10 \%)$. Pemberian daging keong mas pada ikan gabus memberikan pengaruh perubahan arginin. Persentase perubahan arginin dengan pemberian daging keong mas segar sebesar $15,94 \%$ sedangkan yang diberi daging keong mas kering sebesar 26,30\%. Komposisi arginin pada ikan gabus dan daging keong mas disajikan pada Gambar 7.

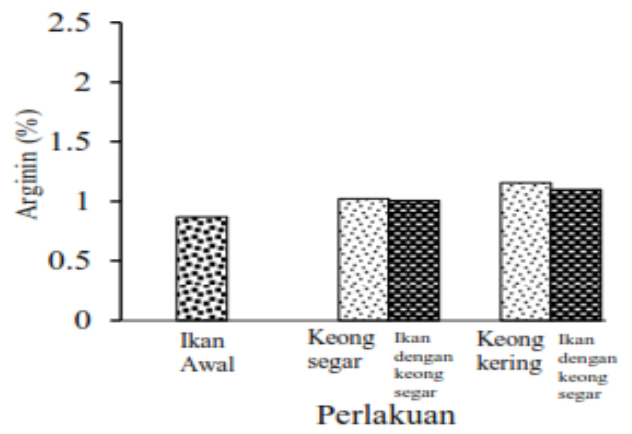

Gambar 7. Komposisi dan persentase perubahan arginin dengan pemberian daging keong mas: Perlakuan A (daging keong mas segar); Perlakuan B (daging keong mas kering).

Komposisi threonin pada ikan gabus awal $(0,73 \%)$. Setelah pemberian daging keong mas dengan komposisi threonin keong mas segar $(0,51 \%)$ dan keong mas kering $(0,68 \%)$, rata-rata komposisi threonin ikan A $(0,73 \%)$ dan ikan B (0,79\%). Pemberian daging keong mas pada ikan gabus memberikan pengaruh perubahan threonin. Persentase perubahan threonin dengan pemberian daging keong mas segar sebesar $0,09 \%$ sedangkan yang diberi daging keong mas kering sebesar 8,59\%. Komposisi threonin pada ikan gabus dan daging keong mas disajikan pada Gambar 8.

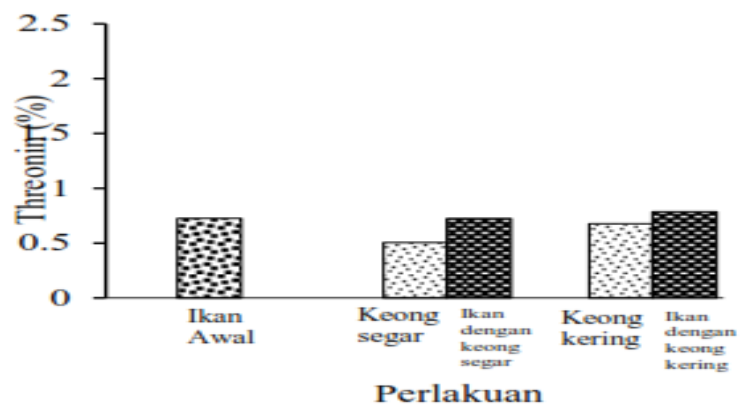

Gambar 8. Komposisi threonin dan persentase perubahan threonin dengan pemberian daging keong mas; Perlakuan A (Pemberian daging keong mas segar); Perlakuan B (Pemberian daging keong mas kering).

Komposisi fenilalanin pada ikan gabus awal $(0,71 \%)$. Setelah pemberian daging keong mas dengan komposisi fenilalanin keong mas segar $(0,42 \%)$ dan 
keong mas kering $(0,58 \%)$, rata-rata komposisi fenilalanin ikan A $(0,80 \%)$ dan ikan B $(0,86 \%)$. Pemberian daging keong mas pada ikan gabus memberikan pengaruh perubahan fenilalanin. Persentase perubahan fenilalanin dengan pemberian daging keong mas segar sebesar $12,67 \%$ sedangkan yang diberi daging keong mas kering sebesar 21,27\%. Komposisi fenilalanin pada ikan gabus dan daging keong mas disajikan pada Gambar 9.

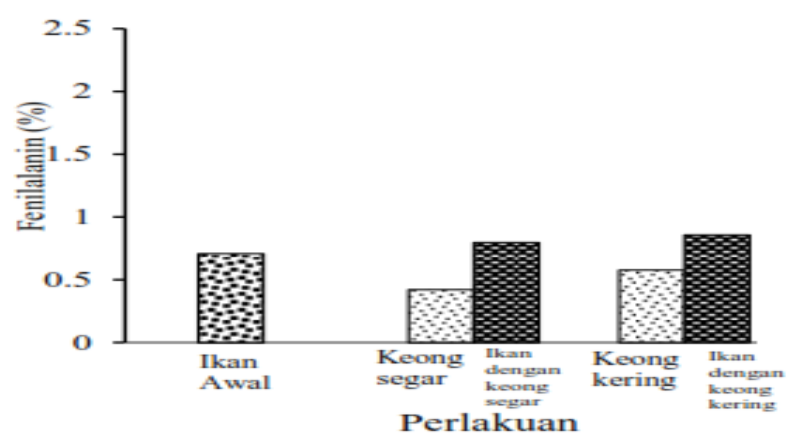

Gambar 9. Komposisi fenilalanin dan persentase perubahan fenilalanin dengan pemberian daging keong mas: Perlakuan A (daging keong mas segar); Perlakuan B (daging keong mas kering).

Komposisi isoleusin pada ikan gabus sebelum pemberian daging keong mas dan setelah pemberian daging keong mas serta isoleusin pada daging keong mas disajikan pada Gambar 10.

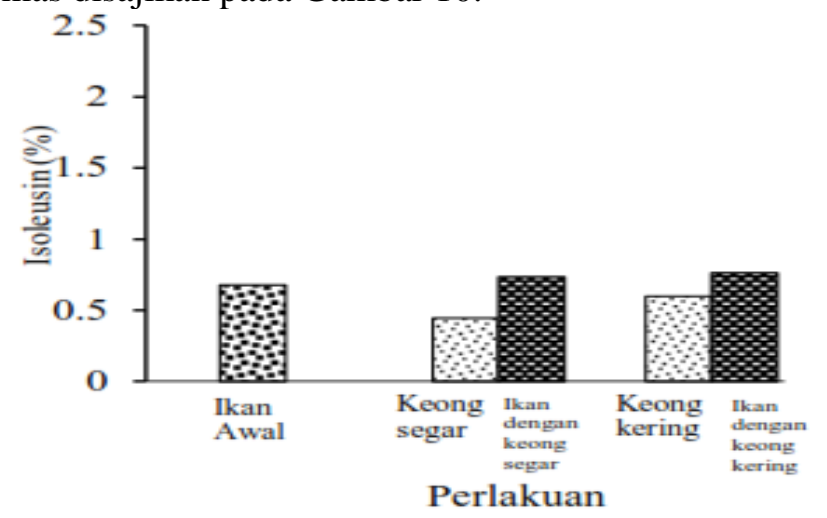

Gambar 10. Komposisi dan persentase perubahan isoleusin dengan pemberian daging keong mas: Perlakuan A (daging keong mas segar); Perlakuan B (daging keong mas kering).

Komposisi isoleusin pada ikan gabus awal $(0,68 \%)$. Setelah pemberian daging keong mas dengan komposisi isoleusin keong mas segar $(0,45 \%)$ dan keong mas kering $(0,60 \%)$, rata-rata komposisi isoleusin ikan A $(0,73 \%)$ dan ikan B $(0,76 \%)$. Pemberian daging keong mas pada ikan gabus memberikan pengaruh perubahan isoleusin. Persentase perubahan isoleusin dengan pemberian daging keong mas segar sebesar 8,28\% sedangkan yang diberi daging keong mas kering sebesar $12,32 \%$.

Komposisi valin pada ikan gabus awal $(0,67 \%)$. Setelah pemberian daging keong mas dengan komposisi valin keong mas segar $(0,48 \%)$ dan keong mas kering $(0,64 \%)$, rata-rata komposisi valin ikan A $(0,73 \%)$ dan ikan B $(0,76 \%)$. Komposisi valin pada ikan gabus dan daging keong mas disajikan pada Gambar 11.

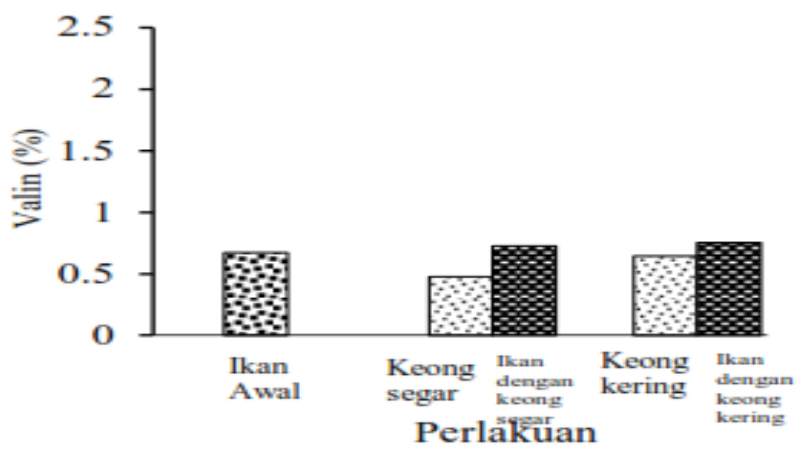

Gambar 11. Komposisi dan persentase perubahan valin dengan pemberian daging keong mas: Perlakuan A (daging keong mas segar); Perlakuan B (daging keong mas kering).

Pemberian daging keong mas pada ikan gabus memberikan pengaruh perubahan valin. Persentase perubahan valin dengan pemberian daging keong mas segar sebesar $8,14 \%$ sedangkan yang diberi daging keong mas kering sebesar 12,37\%.

Komposisi histidin pada ikan gabus awal $(0,52 \%)$. Setelah pemberian daging keong mas dengan komposisi histidin keong mas segar $(0,22 \%)$ dan keong mas kering $(0,23 \%)$, rata-rata komposisi histidin ikan A $(0,62 \%)$ dan ikan B $(0,80 \%)$. Komposisi histidin pada ikan gabus sebelum pemberian daging keong mas dan setelah pemberian daging keong mas serta histidin pada daging keong mas disajikan pada Gambar 12. 


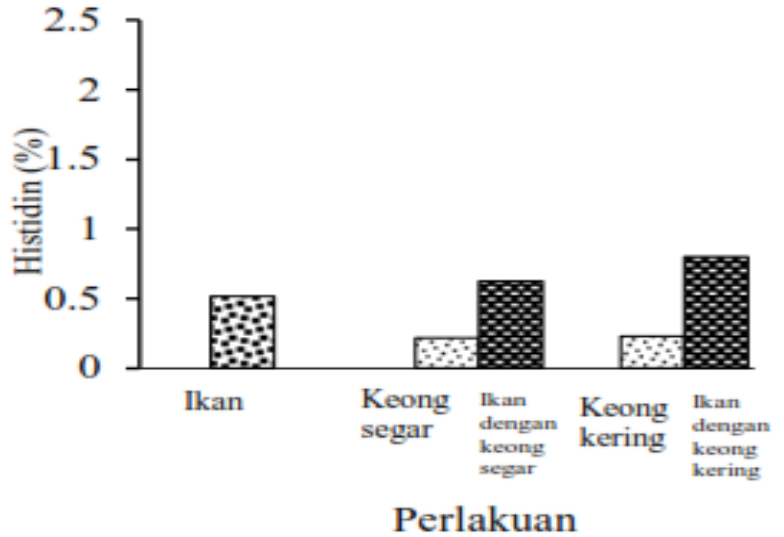

Gambar 12. Komposisi dan persentase perubahan histidin dengan pemberian daging keong mas: Perlakuan A (daging keong mas segar); Perlakuan B (daging keong mas kering).

Pemberian daging keong mas pada ikan gabus memberikan pengaruh perubahan histidin. Persentase perubahan histidin dengan pemberian daging keong mas segar sebesar $21.19 \%$ sedangkan yang diberi daging keong mas kering sebesar 55,52\%.

\section{b. Asam Amino Non Esensial}

Hasil penelitian menunjukan bahwa rata-rata komposisi asam glutamat pada ikan gabus awal $(2,47 \%)$. Setelah pemberian daging keong mas dengan komposisi asam glutamat keong mas segar $(2,15 \%)$ dan keong mas kering $(2,65 \%)$, rata-rata komposisi asam glutamat ikan A $(2,63 \%)$ dan ikan B $(2,51 \%)$. Komposisi asam glutamat pada ikan gabus dan daging keong mas disajikan pada Gambar 13.

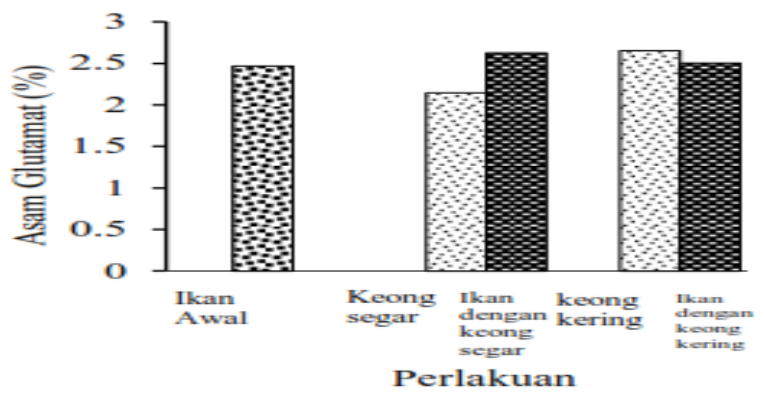

Gambar 13. Komposisi dan persentase perubahan asam glutamat dengan pemberian daging keong mas: Perlakuan A (daging keong mas segar); Perlakuan B (daging keong mas kering).

Pemberian daging keong mas pada ikan gabus memberikan pengaruh perubahan asam glutamat. Persentase perubahan asam glutamat dengan pemberian daging keong mas segar sebesar 6,39\% sedangkan yang diberi daging keong mas kering sebesar $1,52 \%$.

Komposisi asam asparat pada ikan gabus awal $(1,38 \%)$. Setelah pemberian daging keong mas dengan komposisi asam asparat keong mas segar $(1,06 \%)$ dan keong mas kering $(1,36 \%)$, rata-rata komposisi asam asparat ikan A $(1,49 \%)$ dan ikan B $(1,42 \%)$. Komposisi asam asparat pada ikan gabus dan daging keong mas disajikan pada Gambar 14.

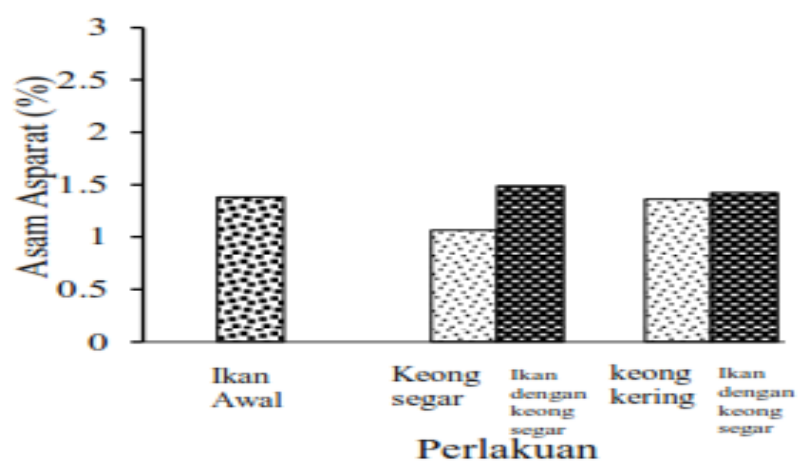

Gambar 14. Komposisi dan persentase perubahan asam asparat dengan pemberian daging keong mas: Perlakuan A (daging keong mas segar); Perlakuan B (daging keong mas kering).

Pemberian daging keong mas pada ikan gabus memberikan pengaruh perubahan leusin. Persentase perubahan asam asparat dengan pemberian daging keong mas segar sebesar $7,54 \%$ sedangkan yang diberi daging keong mas kering sebesar 2,78\%.

Komposisi alanin pada ikan gabus awal $(0,89 \%)$. Setelah pemberian daging keong mas dengan komposisi alanin keong mas segar $(0,74 \%)$ dan keong mas kering $(1,00 \%)$, rata-rata komposisi alanin ikan A $(0,94 \%)$ dan ikan B $(0,91 \%)$. Komposisi alanin pada ikan gabus dan daging keong mas disajikan pada Gambar 15.

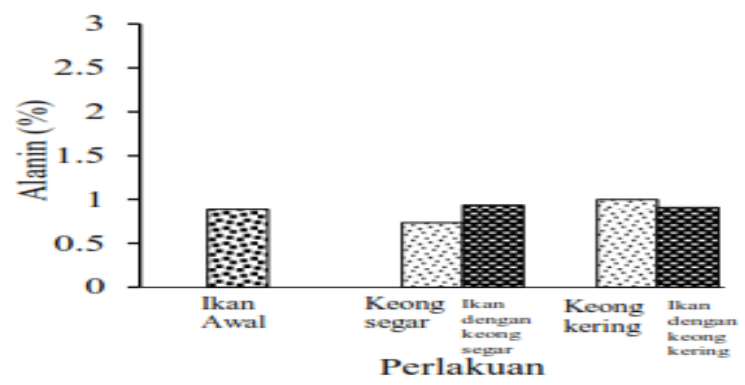

Gambar 15. Komposisi dan persentase perubahan alanin dengan pemberian daging keong mas: 
Jumriati et al.

JURNAL SAINS dan INOVASI PERIKANAN / Journal of Fishery Science and Innovation

Vol. 2, No. 1, 20-29, Januari 2018

Perlakuan A (daging keong mas segar); Perlakuan B (daging keong mas kering)

Pemberian daging keong mas pada ikan gabus memberikan pengaruh perubahan alanin. Persentase perubahan alanin dengan pemberian daging keong mas segar sebesar $5,31 \%$ sedangkan yang diberi daging keong mas kering sebesar $2,15 \%$.

Komposisi glisin pada ikan gabus awal $(0,68 \%)$. Setelah pemberian daging keong mas dengan komposisi glisin keong mas segar $(1,05 \%)$ dan keong mas kering $(1,23 \%)$, rata-rata komposisi glisin ikan A $(0,77 \%)$ dan ikan B $(0,81 \%)$. Komposisi glisin pada ikan gabus sebelum pemberian daging keong mas dan setelah pemberian daging keong mas serta glisin pada daging keong mas disajikan pada Gambar 16.

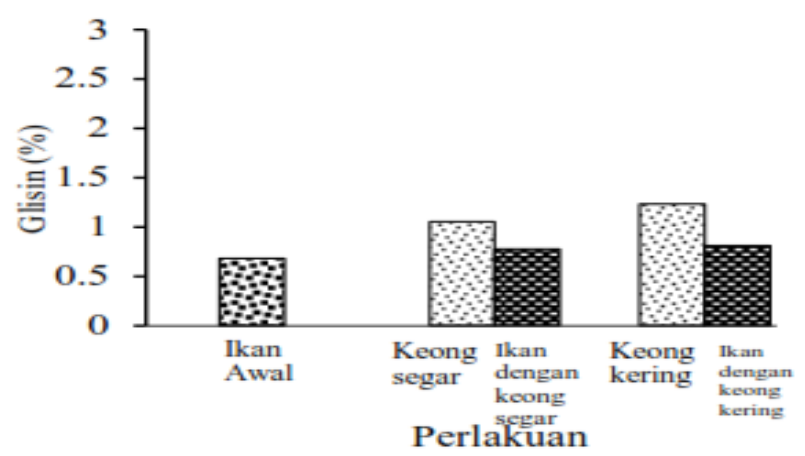

Gambar 16. Komposisi dan persentase perubahan glisin dengan pemberian daging keong mas: Perlakuan A (daging keong mas segar); Perlakuan B (daging keong mas kering).

Pemberian daging keong mas pada ikan gabus memberikan pengaruh perubahan glisin. Persentase perubahan glisin dengan pemberian daging keong mas segar sebesar $13,70 \%$ sedangkan yang diberi daging keong mas kering sebesar 19,29\%.

Komposisi serin pada ikan gabus awal (0,55\%). Setelah pemberian daging keong mas dengan komposisi serin keong mas segar $(0,42 \%)$ dan keong mas kering $(0,56 \%)$, rata-rata komposisi serin ikan A $(0,59 \%)$ dan ikan B $(0,65 \%)$. Komposisi serin pada ikan gabus sebelum pemberian daging keong mas dan setelah pemberian daging keong mas serta serin pada daging keong mas disajikan pada gambar 17 .

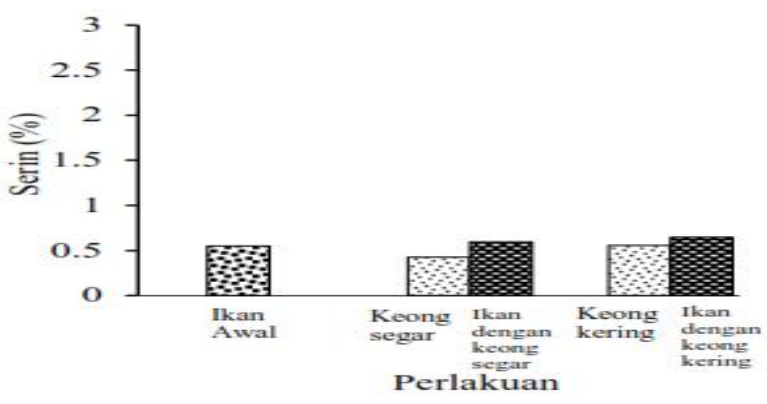

Gambar 17. Komposisi dan persentase perubahan serin dengan pemberian daging keong mas; Perlakuan A (Pemberian daging keong mas segar); Perlakuan B (Pemberian daging keong mas kering).

Pemberian daging keong mas pada ikan gabus memberikan pengaruh perubahan serin. Persentase perubahan serin dengan pemberian daging keong mas segar sebesar 7,98\% sedangkan yang diberi daging keong mas kering sebesar $17,85 \%$.

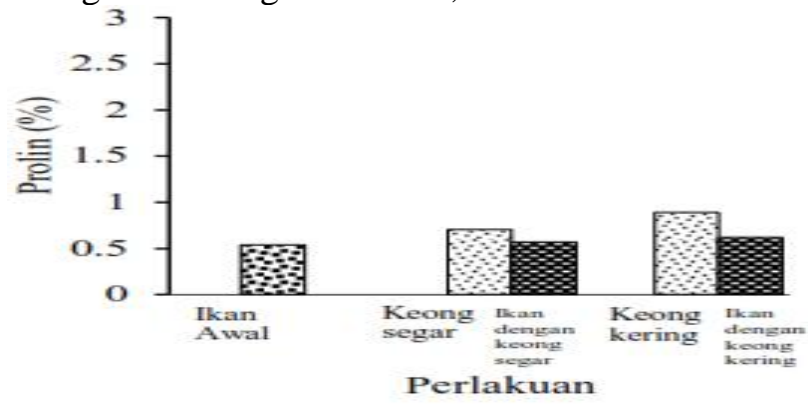

Gambar 18. Komposisi dan persentase perubahan prolin dengan pemberian daging keong mas: Perlakuan A (daging keong mas segar); Perlakuan B (daging keong mas kering).

Komposisi prolin pada ikan gabus awal $(0,54 \%)$. Setelah pemberian daging keong mas dengan komposisi prolin keong mas segar $(0,70 \%)$ dan keong mas kering $(0,89 \%)$, rata-rata komposisi prolin ikan A $(0,57 \%)$ dan ikan B $(60,62 \%)$. Pemberian daging keong mas pada ikan gabus memberikan pengaruh perubahan prolin. Persentase peningkatan prolin dengan pemberian daging keong mas segar sebesar $5,75 \%$ sedangkan yang diberi daging keong mas kering sebesar $15,12 \%$. Komposisi dan persentase perubahan prolin pada ikan gabus dan daging keong mas disajikan pada gambar 18 .

Hasil penelitian menunjukan, total asam amino ikan A $(15,66 \%)$ dan ikan B $(16,02 \%)$. Asam amino esensial ikan A $(8,05 \%)$ dan ikan B $(8,42 \%)$. Asam amino non esensial ikan A $(7,61 \%)$ dan ikan B 
JURNAL SAINS dan INOVASI PERIKANAN / Journal of Fishery Science and Innovation

Vol. 2, No. 1, 20-29, Januari 2018

(7,59\%). Perbandingan total asam amino esensial dan non esensial ikan A $(1,06 \%)$ dan ikan B $(1,11 \%)$.

\section{Pembahasan}

Hasil penelitian selama 60 hari, ikan gabus yang diberi daging keong mas dengan perlakuan pemberian daging keong mas segar dan kering menunjukan perbedaan terhadap pertumbuhan mutlak, retensi protein, dan perubahan asam amino esensial dan non esensial dalam tubuh ikan gabus.

Pemberian daging keong mas dalam bentuk segar memberikan rata-rata pertumbuhan mutlak tertinggi yaitu $2.79 \mathrm{~g}$, bila dibandingkan dengan perlakuan pakan keong mas bentuk kering. Hal ini menunjukan daging keong mas dalam bentuk segar dapat dimanfaatkan dalam pakan buatan. Tingginya pertumbuhan mutlak ikan gabus, disebabkan pakan yang dikonsumsi dapat dimanfaatkan dengan baik. Sudarman (1988), menyatakan kecepatan pertumbuhan tergantung pada jumlah pakan yang dikonsumsi dan kemampuan organisme dalam memanfaatkan pakan yang diberikan. Wyban dan sweenly (1991) menambahkan bahwa pemberian pakan yang tepat baik kualitas maupun kuantitasnya dapat memberikan pertumbuhan yang optimum bagi ikan. Hal ini sesuai dengan penelitian yang dilakukan oleh Firdaus dan Muchlisin (2005), dimana ikan kerapu lumpur yang beri pakan keong mas segar memberikan pertumbuhan yang tinggi yaitu $1.89 \mathrm{~g}$.

Tingginya pertumbuhan ikan gabus dengan pemberian pakan keong mas segar pada penelitian ini didukung pula tingginya retensi protein $1.31 \%$ yang mengambarkan besaran tambahan protein tubuh yang merupakan alokasi protein pakan yang dikonsumsi dengan kualitas bahan pakan yang diberikan. Menurut Soedibya (2013) menyatakan bahwa retensi protein mengekspresikan besarnya tambahan protein tubuh dari protein pakan yang dikonsumsi. Muqaramah (2016), menyatakan bahwa retensi protein mengambarkan pakan yang telah dicerna oleh tubuh ikan serta diserap untuk sintesis protein tubuh.

Mutu protein ditentukan oleh jenis dan proporsi asam amino yang dikandungnya. Protein bermutu tinggi adalah protein yang mengandung semua jenis asam amino esensial dalam proporsi yang sesuai untuk pertumbuhan. Semua protein hewani, kecuali gelatin merupakan protein yang bermutu tinggi (Almatsier, 2001).

Hasil analisis asam amino ikan gabus yang diberi pakan keong mas segar dan kering didapatkan 15 asam amino yang terdiri atas 8 asam amino esensial dan 7 asam amino non esensial. Asam amino esensial yang terdapat pada ikan gabus yang diberi pakan keong mas segar dan kering adalah lisin, leusin, arginin, fenilalanin, isoleusin, valin, threonin, dan histidin. Asam amino non esensial ikan gabus yang diberi pakan keong mas segar dan kering adalah asam glutamat, asam aspartat, alanin, glisin, prolin, tirosin, dan serin. Secara umum, komposisi asam amino yang terdapat pada ikan gabus yang diberi pakan keong mas segar juga terdapat pada ikan gabus yang diberi pakan keong mas kering.

Kandungan asam amino esensial yang tertinggi pada ikan gabus yang diberi pakan keong mas segar maupun kering adalah lisin. Lisin berfungsi sebagai bahan dasar antibodi darah, memperkuat sistem sirkulasi, mempertahankan pertumbuhan sel-sel normal, bersama prolin dan vitamin $\mathrm{C}$ akan membentuk kolagen dan menurunkan kadar trigliserida darah yang berlebihan. Kekurangan lisin dapat menyebabkan mudah lelah, sulit konsentrasi, rambut rontok, anemia, pertumbuhan terhambat, dan kelainan reproduksi (Harli, 2008). Menurut Rosa dan Nunes (2004), arginin, lisin, dan leusin adalah asam amino esensial yang penting pada hewan perairan, oleh karena itu dikenal sebagai sumber tinggi protein.

Komposisi lisin, arginin dan histidin yang terdapat pada ikan gabus tanpa pemberian keong mas telah memenuhi kebutuhan asam amino esensial ikan gabus dan terus mengalami peningkatan setelah pemberian pakan keong mas segar maupun kering. Sedangkan komposisi leusin, threonin, isoleusin dan valin pada ikan gabus tanpa pemberian pakan keong mas maupun dengan pemberian pakan keong mas segar dan kering belum memenuhi kebutuhan asam amino ikan gabus walaupun komposisi leusin, threonin, isoleusin dan valin yang diberi pakan keong mas segar dan kering mengalami peningkatan. Fenilalanin pada ikan gabus tanpa pemberian pakan keong mas belum memenuhi kebutuhan asam aminonya, namun setelah pemberian pakan keong mas segar dan kering, fenilalanin pada ikan gabus mengalami peningkatan dan memenuhi kebutuhan fenilalanin pada ikan gabus.

Tingginya fenilalanin pada ikan gabus dengan pemberian pakan keong mas segar maupun kering, diduga terjadi penghematan penggunaan fenilalanin diakibatkan kelebihan komposisi tirosin dan telah memenuhi kebutuhan asam aminonya. Martin et al. (1981) menyatakan beberapa macam asam amino 
dapat menghemat penggunaan beberapa asam amino lain, akan tetapi tidak dapat menggantikannya secara sempurna. Misalnya: sistin dapat menghemat penggunaan metionin dan tirosin dapat menghemat penggunaan fenilalanin.

Asam amino esensial leusin, arginin, fenilalanin, isoleusin, valin, threonin, dan histidin pada ikan gabus yang diberi pakan keong mas kering cenderung lebih tinggi dibandingkan yang terdapat pada ikan gabus yang diberi pakan keong mas segar. Tingginya asam amino pada ikan gabus yang diberi pakan keong mas kering, oleh karena keong mas kering yang diberikan pada ikan gabus mengandung asam amino yang lebih tinggi bila dibandingkan dengan keong mas segar.

Tinggi komposisi asam amino pada pakan keong mas kering didukung oleh tingginya kadar protein. Kadar protein pada keong mas kering sebesar 26,81\%, sedangkan kadar protein pada keong mas segar sebesar $16,26 \%$. Kandungan protein keong mas kering lebih tinggi disebabkan kadar air pada keong mas kering lebih rendah dibandingkan keong mas segar, sehingga secara proposional akan meningkatkan kadar proteinnya. Semakin rendah kadar air, maka konsentrasi protein di dalam bahan semakin pekat, sehingga presentasinya akan terlihat lebih besar. Hal ini didukung oleh Tapobun et. al. (2008), yang menyatakan bahwa keluarnya air dari bahan pangan menyebabkan protein lebih terkonsentrasi dibandingkan dengan yang lain sehingga kandungan asam aminonya lebih baik.

Asam amino pembatas adalah asam amino yang berada pada jumlah sedikit, sehingga disebut sebagai asam amino pembatas (Harris \& Karmas, 1989). Asam amino pembatas pada ikan gabus baik yang diberi pakan keong mas segar maupun pakan keong mas kering adalah histidin. Kandungan histidin pada ikan gabus yang diberi pakan keong mas segar adalah $6.245,1 \mathrm{ppm}$, ikan gabus yang diberi pakan keong mas kering adalah 8.013,8 ppm. Menurut Selcuk et. al. (2010). Histidin berfungsi dalam pertumbuhan dan perbaikan jaringan tubuh serta memproduksi sel darah merah. Asam amino non esensial pembatas pada ikan gabus yang diberi pakan keong mas segar maupun keong mas kering adalah prolin.

Asam amino non esensial yang tertinggi pada ikan gabus yang diberi pakan keong mas segar maupun kering adalah asam glutamat. Asam glutamat bermanfaat untuk mengendalikan keinginan konsumsi alkohol berlebih, mempercepat penyembuhan luka pada usus, meningkatkan kesehatan mental dan meredam emosi (Linder, 1992). Asam glutamat merupakan asam amino yang paling banyak dimetabolisme dalam tubuh, selain itu tingginya kadar asam glutamat pada ikan gabus yang diberi pakan keong segar dan kering disebabkan oleh deaminasi asam amino glutamin menjadi asam glutamat (Murray et al. 2003).

Asam amino esensial pada ikan gabus sebelum pemberian pakan keong mas yang telah memenuhi kebutuhan asam amino esensial ikan gabus adalah lisin, arginin dan histidin. Setelah pemberian pakan keong mas segar maupun kering fenilalanin juga memenuhi kebutuhan asam amino esensial ikan gabus. Sementara leusin, isoleusin, valin dan threonin, terjadi penambahan jumlah komposisi asam amino namun belum memenuhi kebutuhan asam amino pada ikan gabus baik yang diberi pakan keong mas segar maupun pakan keong mas kering.

Kualitas air mempunyai peranan penting sebagai pendukung kelangsungan hidup bagi organisme budidaya. Suhu wadah pemeliharan selama penelitian yaitu $26{ }^{\circ} \mathrm{C}$ dan oksigen terlarut selama penelitian berkisar antara 4,1-4,3 mg/L. Hasil pengukuran $\mathrm{pH}$ yang didapatkan pada saat penelitian yakni 6 . Pengukuran kadar amoniak selama penelitian adalah $0,030 \mathrm{mg} / \mathrm{L}$.

\section{KESIMPULAN}

Berdasarkan hasil penelitian dapat disimpulkan bahwa budidaya ikan gabus dengan pemberian pakan keong mas segar memberikan pengaruh pada pertumbuhan dan retensi protein yang tinggi pada ikan gabus. Total asam amino dan asama amino esensial pada ikan gabus lebih baik dengan pemberian pakan keong mas kering.

\section{DAFTAR PUSTAKA}

Almatsier S. 2006. Prinsip Dasar Ilmu Gizi. Jakarta: Gramedia Pustaka Utama.

Firdaus, Muchlisin ZA. 2005. The possibility of golden snail (Pomacea analiculata) as an alternative feed for cultured grouper (Epinephelus tauvina). PPLH-LPPM UNS. Enviro 5 (1):64-66

Harris RS, Karmas E. 1989. Evaluasi Gizi pada Pengolahan Bhan Pangan Edisi ke-2. Bandung: ITB Press.

Harli M. 2008. Asam amino esensial. http://www.supamas.com [15 Oktober 2017]. 
JURNAL SAINS dan INOVASI PERIKANAN / Journal of Fishery Science and Innovation

Vol. 2, No. 1, 20-29, Januari 2018

Harver JE. 1988, Fish Nutrition 2 nd Academic Press inc. $713 \mathrm{pp}$

Linder MC. 1992. Biokomia Nutrisi dan Metabolisme. Jakarta: Universitas Indonesia Press.

Martin DW, Hayes PA, Rodwell W. 1981. Harper's Review of Biochemistry, $18^{\text {th }}$ Ed. California: Medical Publication.

Muqaramah TMHA. 2016. Pemberian Kadar Protein Pakan Berbeda Terhadap Pertumbuhan Udang Vaname dengan Tehnologi Bioflok pada Kegiatan Pendederan [Tesis]. Bogor. Institute Pertanian Bogor.

Murray KK. Granner DK, Mayes PA, Rodwell VW. 2003. Biokimia Harper. Jakarta: Buku kedokteran EGC.

Rosa R, Nunes ML. 2004. Nutritional quality of red shrimp (Aristeus antennatus), pink shrimp (Parapenaeus longirostris), and Norway lobster (Nephrops norvegicus). J Sci Food Agric 94(2004): 84-89.

Soedibya PHT. 2013. Retensi Protein pada Ikan Nila GIFT (Oreochromis niloticus) yang Diberi Pakan Azola Pinnata dengan Diperkaya Mikroba Probiotik. Jurnal Akuakultur Indonesia 12(2):109113.

Sudarman. 1988. Budidaya Udang Windu. Pembesaran Di Tambak. Surabaya: Agricultural Tehnical Boston W.D.C.

Tapotubun AM, Nanlohy E, Louhenapessy J. 2008. Efek waktu pemanasan terhadap mutu presto beberapa jenis ikan. Ichthyos 7(2): 65-70.

Wyban JA, Sweeny JN. 1991. Intensif Shrimp Production Technology. Honolulu, Hawai USA: The Oceanic Institute. 